\title{
湛水によるアゼガヤ（Leptochloa chinensis Nees）の出芽抑制
}

\author{
住吉 正 $^{*}$
}

キーワード: アゼガヤ, 出芽, 水田雑草, 湛水条件, 発芽

Keywords: red sprangletop, emergence, paddy weeds, flooded conditions, germination

\section{緒言}

近年, 九州地域の水田や大豆畑でアゼガヤ (Leptochloa chinensis Nees) の発生が目立ってきている (住吉 2008b)。水田に扔けるアゼガヤの防除に関して は, 除草剤による防除（大谷 1997 ：住吉 2008a) の他に，湛水による出芽抑制と生育抑制の可能性が 示されており（川名 1999：松尾ら 1987），比較的容 易に防除できると考えられている。しかしながら，現状 ではそれらの防除効果は十分には発揮されていないと 言わざるを得ない。著者らは，湛水によるアゼガヤの 防除効果を検証するため, これまでに出芽後の生育 に及ぼす湛水の影響について明らかにした（住吉ら 2007)。その結果, 1〜2 葉期程度のごく小さなアゼガ ヤは，湛水による生育抑制を大きく受けるものの，1力 月程度の湛水では完全には枯死しないことが判明し た。そこで, 本稿では湛水によるアゼガヤの出芽抑制 に焦点を当て, 湛水代かき条件からの出芽に関わるい くつかの要因について検討した。

\section{材料および方法}

2007 年秋に九州沖縄農業研究センター（福岡県 筑後市）内の試験围場に自然発生した集団から採集 したアゼガヤ種子を，風乾した後， $0.25 \mathrm{~mm}$ 目で篩っ た水田土壤（沖積軽埴土）とともに透水性のあるナイ ロン袋に入れ，2007 年 10 月 3 日に水田土壤を詰めた

\footnotetext{
*九州沖縄農業研究センター $=833-0041$ 福岡県筑後市大 字和泉 496 tadashis@affrc.go.jp

Tadashi Sumiyoshi*: The inhibition of red sprangletop (Leptochloa chinensis Nees) emergence with flooded soil conditions.

*National Agricultural Research Center for Kyushu Okinawa Region, 496 Izumi, Chikugo, Fukuoka 833-0041, Japan. (2009 年 1 月 22 日受付, 2009 年 4 月 7 日受理)
}

1/5,000a ポットの土中 $5 \mathrm{~cm}$ に埋没した。ポットは屋外 に置き, 適宜灌水し, 翌年種子を回収して以下の試 験に供した。なお，アゼガヤには「そう生型」と「ほ ふく型」の 2 型が知られる（松尾・片岡 1981a）が, 本試験で用いたアゼガヤは「ほふく型」にあたる。

試験 1 (発芽試験)：2008 年 3 月 26 日, 4 月 23 日, 5 月 22 日，6月 23 日， 7 月 22 日および 8 月 26 日に種 子を土壤から回収して，その日のうちに湿潤ろ紙床お よび密栓水中条件での発芽試験に供した。湿潤乃紙 床では径 $6 \mathrm{~cm}$ のシャーレを用い, ろ紙を1枚敷いて蒸 留水で湿潤状態とし, 種子を 50 粒ずつ置床した。 シャーレは, $15,20,25,30$ および $35^{\circ} \mathrm{C}$ の定温器 に入れ， 12 時間日長の明条件で 20 日間の発芽数を 調査した (明条件)。また, 暗条件として, 種子を置 床後, シャーレ全体をアルミホイルで包んだ区を設け, 置床後 15 日目に発芽数を調査した。密栓水中条件 では $10 \mathrm{ml}$ 容サンプル管瓶を用い, 蒸留水を満たして 種子を 50 粒ずつ沈め, 栓をした。その後, 15,20 , 25,30 および $35^{\circ} \mathrm{C}$ の定温器に入れ， 12 時間日長の 明条件で 15 日間の発芽数を調査した。いずれの試験 も各 3 反復とした。

試験 2 (出芽試験)：2008 年 4 月 28 日, 5 月 20 日, 6 月 26 日および 7 月 23 日に種子を土壌から回収して, その日のうちに出芽試験に供した。1/5,000a ポットを用 い, 殺種子処理をした水田土壤を詰めて湛水代かき した。回収した種子をポット当たり 50 粒ずつ播種し, 土壤表層約 $2 \mathrm{~cm}$ を再度代かきた。ポットは, 上部 のみをビニールで覆い雨よけをしたハウス内に置き, 落 水区と常時湛水区を設けた。落水区では, その日のう ちにポットの下栓を抜いて落水し, 以降は 1 日 1 回灌 水を行った。常時湛水区は, 概小 $3 \mathrm{~cm}$ の湛水深を 維持した。各区 5 反復とし, 播種後 30 日間の出芽数 を調査した。

\section{結果}

発芽試験（試験 1）の結果を第 1 眓に示した。湿 潤乃紙床・明条件では, 置床温度 $20^{\circ} \mathrm{C}$ 以上では発 芽率は回収時期にかかわらず比較的高く推移したが, 
置床温度 $15^{\circ} \mathrm{C}$ では, 3 月の回収では全〈発芽せず, 以降 6 月までは回収時期が遅〈なるに従って発芽率が 向上した。

湿潤乃紙床・暗条件では，置床温度 $20^{\circ} \mathrm{C}$ 以上で は 3 月から 7 月まで回収時期が遅くなるに従って発芽 率が向上した。置床温度 $15^{\circ} \mathrm{C}$ では, 3 月および 4 月 の回収ではほとんど発芽せず，5月以降発芽率が向 上したが，6月の回収時の発芽率は 5 月のそれに比 べて若干低かった。また，いずれの置床温度におい ても，3 月から 6 月の回収での発芽率は湿潤ろ紙床・ 明条件でのそれよりも常に低い值を示した。

一方, 密栓水中・明条件では, 置床温度 $20^{\circ} \mathrm{C}$ 以上では発芽率は回収時期にかかわらず比較的高く 推移し, 湿潤ろ紙床・明条件での発芽率と同様な傾 向を示した。しかしながら, 置床温度 $15^{\circ} \mathrm{C}$ では, 発 芽率は他の置床温度条件よりも若干低い傾向が認め られたものの，3 月および 4 月の回収で，それぞれ $79 \%$ および $84 \%$ を示し，湿潤ろ紙床・明条件での発 芽率よりも高い值を示した。5 月以降の回収では湿潤 ろ紙床・明条件での発芽率とほぼ同等に推移した。 な押, 密栓水中条件で発芽した種子は, 水面への浮 上が認められた。

出芽試験（試験 2）の結果を第 2 図に示した。落 水区における出芽は良好で, 4 月から 7 月までの試験 範囲では, 回収時期が遅いほど出芽率が高まり, 最 大で約 $60 \%$ となった。一方, 常時湛水区に打けるア ゼガヤの出芽はごくわずかで，出芽率は最大でも約 $3 \%$ （6月26日回収分）にとどまったが，いずれの回収時 期においても出芽は認められた。

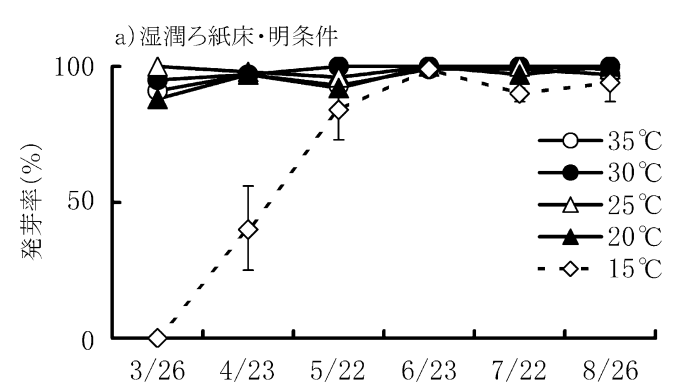

b) 湿潤ろ紙床・暗条件

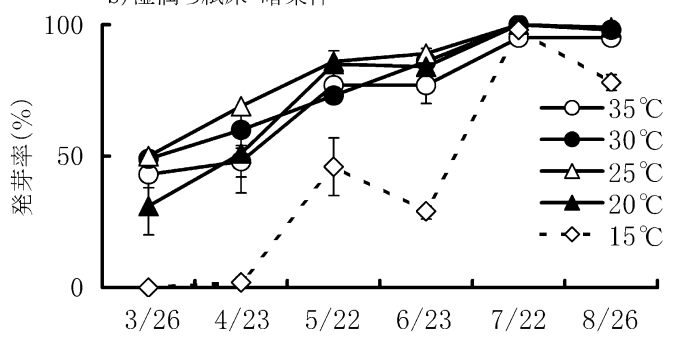

c) 密栓水中・明条件

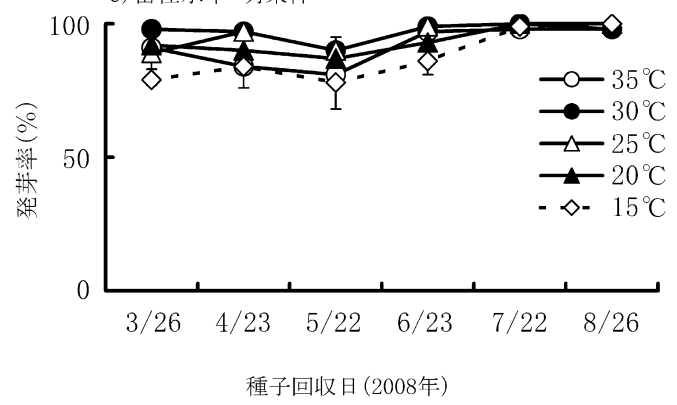

第 1 図 各時期に回収したアゼガヤ種子の発芽率に及ぼす 発芽床および温度の影響

各 50 粒 3 反復, 湿潤万紙床. 明条件は 20 日間, 他は 15 日間の発芽率。エラーバーは標準誤差。

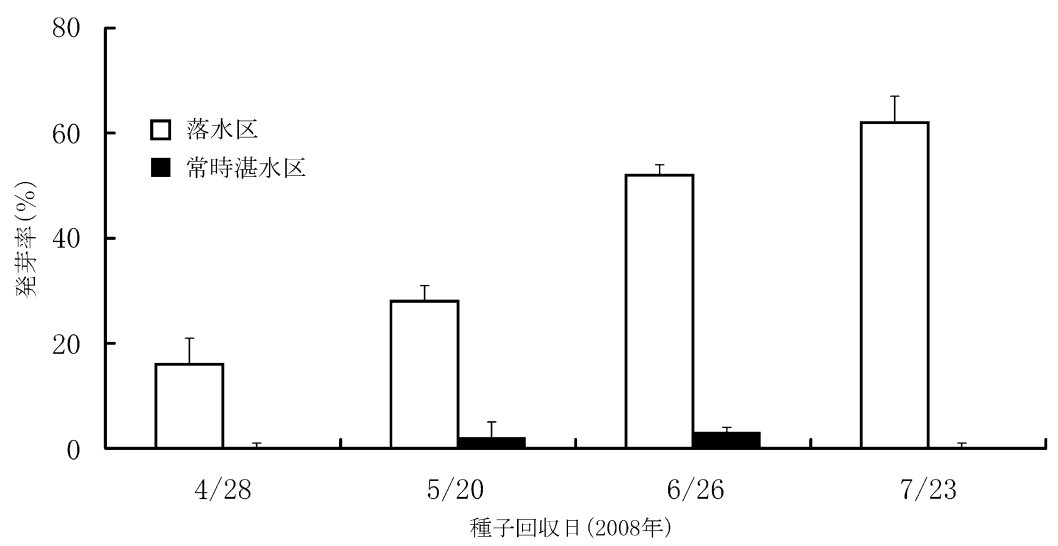

第2図アゼガヤの出芽に及ぼす水管理の影響

1/5,000a ポットに各 50 粒 5 反復で播種して湛水代かきした。落水区は当日落水。屋外条件で 30 日 間の出芽率。エラーバーは標準誤差上限值。 


\section{考察}

アゼガヤ種子の発芽に関する国内の報告では, 種 子の発芽には光（笠原 1940 : 森田 1968）や変温 （笠原 1941）が有効であること, $15 \sim 45^{\circ} \mathrm{C}$ の範囲で 発芽可能で, 発芽適温は $35 \sim 40^{\circ} \mathrm{C}$ であること（森 田 1968）が示されている。本試験 1 の湿潤ろ紙床に よる結果は，秋期に土中に埋没された種子は，翌年 の春期には，発芽に最適な条件であれば十分に発芽 可能な程度にまで休眠覚醒が進んでいること, その後 夏期に向けて埋没期間の延長とともに休眠覚醒がさら に進行し, 発芽に打ける光や温度に対する要求度が 低下していくこと示している。このような休眠覚醒程 度の状態にある種子の密栓水中条件での発芽率は, 湿潤ろ紙床条件のそれと同等以上であり，休眠覚醒 が進行したアゼガヤ種子は，水中でも良好に発芽する ことが明らかとなった。

本試験 2 の落水区では，種子の回収時期が遅くな るに従って出芽率の向上が認められたが, 回収時期 の違いによる種子の休眠覚醒程度の違いと, 試験期 間中の気温の違いが反映された結果と考えられる。

アゼガヤの出芽に関するこれまでの報告では, 常時 湛水条件では全く発生しなかったという結果（川名ら 2005：松尾ら 1987）と, 湛水下でも発生し, その後 表土剥離とともに水面に浮上して良好に生育した（松 尾ら 1987）という結果が示されている。また，畑水分 区に比べて飽水区での出芽数が著しく少なかったこと が示されている（松尾ら 1981b）。本試験 2 の常時湛 水区では, いずれの回収時期においても出芽率が極 めて低かったものの, 若干の出芽は認められた。これ らのことから, アゼガヤは湛水代かきされた条件でも, ごくわずかは出芽可能であるが，湛水はアゼガヤの出 芽を大きく抑制すると結論付けられる。

一般的に，湛水による出芽抑制は嫌気的条件（低 酸素条件）による発芽阻害が最も大きな要因と考えら れるが, 本試験 1 の密栓水中での発芽は良好であっ た。したがって, 湛水による低酸素条件は出芽抑制 の直接的な原因とはなっていないと考えられる。また, 暗条件での発芽も比較的良好で，特に7月の回収で は $15 \sim 35^{\circ} \mathrm{C}$ の全温度域でほぼ $100 \%$ の発芽率が得 られており，種子が土中にあることによる遮光条件は 発芽抑制には働いていないと考えられる。

アゼガヤ種子の発芽および出芽に関してはイ多アお よびフイリピンにおいても詳細に検討されている。日本
産種子の頴果の千粒重は本試験の供試材料が $78 \mathrm{mg}$, 榎本（1992）によれば $55 \mathrm{mg}$ であるが, イ夕 リア産種子は，頴果の千粒重が $142 \mathrm{mg}$ (Benvenuti et al. 2004）で日本産種子よりも大きく, フィル゚゚ン産種 子は, 重量がイ夕リア産の半分以下 (Chauhan and Johnson 2008) とされ，日本産種子と同程度と推察さ れる。イ多ア産種子には休眠性が無く, 発芽には酸 素分圧は影響せず，光および変温が発芽を促進する ことが示されている (Benvenuti et al. 2004)。また, 湛水下での出芽は良好であり, 埋土深度や湛水深の 増加は種子の発芽自体は阻害しないが, 幼芽の伸長 不足による出芽率の低下が報告されている（Benvenuti et al. 2004)。一方, フィリピン産種子は, 休眠性は 無く, 発芽には光が絶対的に必要であるとされ, $0.5 \mathrm{~cm}$ 以上の埋土条件では全く出芽せず, 湛水に よって出芽率と生育が抑制されることが示されている (Chauhan and Johnson 2008)。

いずれも，本試験の結果や国内の既往の報告と一 部異なる特性を示しており, 直接の比較は困難である が，イ夕リアでの試験結果を参考にすれば，湛水土中 でもアゼガヤは発芽しており，幼芽の伸長不足によっ て出芽に至らなかった可能性も否定できない。

土中で発芽した種子が出芽できるかどうかは，種子 の貯蔵養分の多少に依存し, イ多ア産種子は日本産 およびフイリピン産種子の 2 倍以上の重さがあり, より 深い深度からも出芽可能であることが推察される。国 内におけるアゼガヤの出芽深度は平均 $0.5 \mathrm{~cm}$ 程度と 報告（野田・江口 1969）され，前述のフイリピンでの 結果と類似しており, イタリアでの結果（播種深度 $4 \mathrm{~cm}$ でも $20 \%$ 程度の出芽率）と大き〈異なっている。 日本産アゼガヤがイ夕リア産アゼガヤに比べて土中から の出芽能力に劣ることも本試験結果の一因となってい ると考えられる。本試験 2 では, 未出芽種子の土中 での発芽の有無については調査していないが, 今後 の詳細な検討が期待される。

従来, アゼガヤの防除に打いては湛水維持の重要 性が指摘されてきたが (Chin 2001)，本試験の結果 は，日本産アゼガヤに限って言えば，単なる湛水だけ でなく, 湛水代かき土ん種子を埋没させることで発 生が抑制されることを示しており，田面を代かきした上 で湛水を維持することがアゼガヤの防除には有効であ る。 


\section{引用文献}

Benvenuti, S., G. Dinelli and A. Bonetti 2004. Germination ecology of Leptochloa chinensis : a new weed in the Italian rice agro-environment. Weed Research 44, 87-96.

Chauhan, B.S. and D.E. Johnson 2008. Germination ecology of Chinese sprangletop (Leptochloa chinensis) in the Philippines. Weed Science 56, 820-825.

Chin, D.V. 2001. Biology and management of barnyardgrass, red sprangletop and weedy rice. Weed Biology and Management 1,37-41.

榎本敬 1992. 日本産雑草種子に関する研究. 第 2 報 単子葉植物の種子重量について. 雑草研究 37 (別 I), 130-131.

笠原安夫 1940. 雑草種子の発芽の研究（第 1 報）(1) 発芽に及ぼす光線の影響. 農及園 15, 1815-1823.

笠原安夫 1941. 雑草種子の発芽の研究（第2 報）(2) 発芽に及ぼす変温の影響, (3) 発芽床と発芽との関 係。農及園 16, 436-444.

川名義明 1999. 初期落水管理を行なう水稲湛水直播栽 培における湿生雑草 4 草種の発生消長と除草剤の効 果. 日作九支報 $65,33-35$.

川名義明 ·住吉正 ·巟嶋清 2005. 水稲湛水直播栽培に
おける主要雑草の発生に及ぼす播種後落水管理の影 響. 九州沖縄農研研究資料 91, 75-78.

松尾喜義・片岡孝義 1981a. アゼガヤの変異型. 雑草研 究 $26,39-41$

松尾喜義・片岡孝義 1981b. アゼガヤの出芽に及ぼす土 壤水分と土壌攪拌時期の影響. 雑草研究 26, 239-242.

松尾喜義·片山信浩 - 金忠男 - 小松良行 · 上村幸正 1987. イネ科雑草アゼガヤの生態と防除. 四国農試報 48, 1-15.

森田林逸 1968. アゼガヤの生態 (予報). 日本作物学会 四国支部紀事 6,29-33.

野田健児 - 江口未馬 1969. 雑草の発生深度と幼苗期生 態について (雑草の生態に関する研究 第2 報). 日 本雑草防除研究会第 8 回講演会講演要旨, 77-79.

大谷晴一 1997. アゼガヤに関する研究：第一報 北部九州 での発生と数種除草剂の効果. 雑草研究 42(別), 146-147.

住吉正 · 小荒井晃・保田謙太郎 2007 . アゼガヤの冠水 に対する生育反応，杂隹草研究 52, 185-189.

住吉正 2008a. アゼガヤに対する各種除草剤の防除効 果. 日作九支報 74, 56-58.

住吉正 2008b. アゼガヤ等田畑共通雑草の九州地域の水 田作地带における発生状況. 九州の雑草 38, 8-11. 